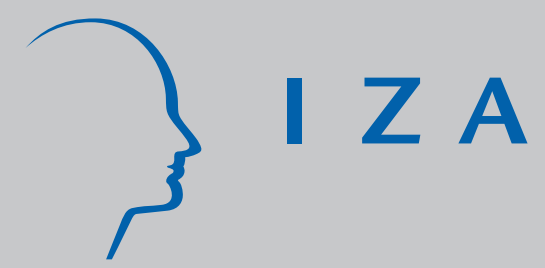

IZA DP No. 10314

Which Are the Benefits of Having More Female Leaders?

Evidence from the Use of Part-Time Work in Italy

Francesco Devicienti

Elena Grinza

Alessandro Manello

Davide Vannoni

October 2016 


\title{
Which Are the Benefits of Having More Female Leaders? Evidence from the Use of Part-Time Work in Italy
}

\author{
Francesco Devicienti \\ University of Turin, Collegio Carlo Alberto and IZA \\ Elena Grinza \\ University of Turin \\ Alessandro Manello \\ University of Turin \\ Davide Vannoni \\ University of Turin and Collegio Carlo Alberto
}

Discussion Paper No. 10314

October 2016

\author{
IZA \\ P.O. Box 7240 \\ 53072 Bonn \\ Germany \\ Phone: +49-228-3894-0 \\ Fax: +49-228-3894-180 \\ E-mail: iza@iza.org
}

Any opinions expressed here are those of the author(s) and not those of IZA. Research published in this series may include views on policy, but the institute itself takes no institutional policy positions. The IZA research network is committed to the IZA Guiding Principles of Research Integrity.

The Institute for the Study of Labor (IZA) in Bonn is a local and virtual international research center and a place of communication between science, politics and business. IZA is an independent nonprofit organization supported by Deutsche Post Foundation. The center is associated with the University of Bonn and offers a stimulating research environment through its international network, workshops and conferences, data service, project support, research visits and doctoral program. IZA engages in (i) original and internationally competitive research in all fields of labor economics, (ii) development of policy concepts, and (iii) dissemination of research results and concepts to the interested public.

IZA Discussion Papers often represent preliminary work and are circulated to encourage discussion. Citation of such a paper should account for its provisional character. A revised version may be available directly from the author. 
IZA Discussion Paper No. 10314

October 2016

\section{ABSTRACT \\ Which Are the Benefits of Having More Female Leaders? Evidence from the Use of Part-Time Work in Italy}

Using three waves of a uniquely rich survey on Italian private firms, we explore the impact of female managers on the use of part-time work. Building on a literature arguing that female leaders are more sensitive to their employees' needs and more self-transcendent than their male counterparts, we assess whether such attitudes manifest themselves also in relation to working time arrangements. Results indicate that female managers are indeed more responsive to their employees' needs: they heavily limit the employment of involuntary parttime work, correspondingly increasing full-time employment, and concede more part-time arrangements to employees asking for them. All in all, our results show that there are some hitherto unexplored benefits from increasing the number of female leaders: on the one hand, they strongly contain the widespread phenomenon of involuntary part-time employment and, on the other hand, they enhance the work-life balance of workers engaged in child care or elderly care activities.

JEL Classification: J23, J41, M51

Keywords: female managers, part-time work, involuntary part-time work, work-life balance, meeting employees' needs, self-transcendence

Corresponding author:

Elena Grinza

Department of Economics

University of Turin

Corso Unione Sovietica 218 Bis

10134, Turin

Italy

E-mail: elena.grinza@unito.it 


\section{Introduction}

Since the mid-1970s, part-time work has become increasingly popular, and now it represents a pervasive feature of work arrangements. According to the Italian statistical office (Istat), in Italy, the share of employees working on a part-time basis was around $15 \%$ in 2010. Due to its reduced working time, part-time work is commonly regarded as a work-life balance instrument, and for many part-timers this is indeed the case. However, much less is known about its dual nature: many part-time workers (Istat reports that they were as many as $49 \%$ in Italy in 2010) declare themselves to be employed part-time against their will, that is, they would prefer to work full-time but they could not find any full-time job. For this reason, involuntary part-time employees enter the count of underemployed people. Hence, while voluntary part-time work should be encouraged by policy makers as it helps to better conciliate work with family, involuntary part-time work represents a social scourge that they should try to eradicate.

Several studies suggest that female leaders differ from their male counterparts in terms of preferences and behavior: women leaders are found to be more self-transcendent (Adams and Funk, 2012) and more prone to respond to others' needs (Eagly and Carli, 2007). While women remain heavily underrepresented in leadership positions (according to Istat only $22 \%$ of top and middle managers were females in 2008 in Italy), the number of female leaders is rapidly growing in the recent years, also in response to active policies aiming at increasing female participation in key positions.

Thus, if women leaders are indeed more empathetic and benevolent than men leaders, women leaders may play a crucial role in meeting employees' needs regarding, among the other things, working time arrangements. They may grant more part-time positions to employees asking for it (i.e., increase work-life balance of workers) and provide more fulltime jobs to employees aspiring to it (i.e., limit the phenomenon of involuntary part-time work). The aim of the paper is to assess whether this actually happens and to what extent.

While the literature investigating the economic outcomes of female leadership has rampantly grown in the last years, to the best of our knowledge, no paper specifically analyzes the effect of female leaders on a firm's use of part-time work.

To perform the empirical analysis, we use three waves (for the years 2005, 2007, and 2010) of the Employer and Employee Survey (RIL), conducted by the Institute for the Development of Workers' Vocational Training (ISFOL). The RIL data set collects a representative sample of Italian firms and contains uniquely rich information concerning the adoption of part-time work, including the reason for its use.

A preliminary investigation of the impact of female leaders on part-time work performs OLS regressions with large sets of controls for potentially confounding observable factors. 
Unobserved heterogeneity is dealt with through fixed-effects (FE) and instrumental variable (IV) estimation. In all the specifications, the use of part-time work by the firm is measured as the share of part-time employees over the total number of employees. Correspondingly, the presence of female leaders in the firm is measured as the share of female managers over the total number of managers. Throughout the analysis, 'managers' refer to both the top and the middle management of the firm.

The primary finding, robust to controls for several observable factors and unobserved heterogeneity, is that female managers significantly limit the use of part-time work. However, if the involuntary and voluntary components of part-time work are not distinguished, it is hard to understand what is really going on behind this result.

Since we do not have any direct information on the number of voluntary and involuntary part-timers employed in the firm, we have to exploit indirect information on this. Using available information on the reason why the firm adopts part-time work - whether it is to satisfy employees' needs for shorter working hours or, conversely, the result of a deliberate corporate strategy -, it is possible to individuate the group of firms employing the involuntary part-time workers. In fact, it is reasonable to assume that the involuntary part-timers are employed in firms using part-time work to satisfy their (the firms') needs rather than in firms accommodating workers' requests for part-time work. Hence, we proceed by splitting the sample of firms using part-time work on the basis of their motivation and by estimating the impact of female managers on part-time work for the two groups of firms.

Firstly, we find that in firms using part-time work to fulfill their own interests, the effect of female managers is negative, strongly significant, and very large in magnitude, especially when controlling for unobserved time-invariant heterogeneity. This result is in line with the idea that female managers limit the employment of involuntary part-timers, correspondingly providing more full-time employment. To corroborate this interpretation, we show that female managers operating in local contexts of high involuntary part-time work or unemployment are associated with a significantly higher decrease in the use of part-time work compared to those operating in contexts of low involuntary part-time work or unemployment, thus indicating that they indeed limit the involuntary (rather than the voluntary) component of part-time work.

Secondly, we find that in firms using part-time work to accommodate workers' needs, female managers have no significant effect on the use of part-time work. In contrast with our expectations, this result suggests that female managers do accommodate employees' requests for part-time work as much as male managers do.

However, since the motivation for the use of part-time work is obviously self-reported by the firm and there is no way of checking its truthfulness, it may well happen that some firms 
lie about their real motivation and answer in a socially desirable way: they may declare to use part-time work to satisfy their employees' needs while, truly, they use it to satisfy the firm's needs. If this is the case, the group of firms declaring to use part-time work to satisfy workers' needs, actually includes a proportion of firms using it strategically (while the group of firms declaring to use it strategically most likely includes only firms honestly telling their motivation, since there is no evident reason for them to lie), thus mudding the last result.

To explore this possibility, we perform separate FE regressions on firms using part-time work depending on how much part-time work they use. The rationale is that firms using part-time arrangements to accommodate workers' requests tend to use it less intensively compared to firms for which part-time work is the result of a deliberate corporate strategy. This implies that among firms using low levels of part-time work it is most likely to find firms that truly use it as an accommodation instrument, thus allowing us to test if female managers do accommodate workers' request for part-time work more than their male counterparts do, as expectations would suggest.

This check confirms our expectation. In firms using relatively low levels of part-time work, female managers are found to significantly increase the amount of part-time arrangements, thus indicating that they concede more part-time work to employees asking for it compared to their male counterparts.

In conclusion, in line with the literature arguing that females tend to be more selftranscendent and generous than men, female managers meet their employees' needs in terms of working time arrangements more than male managers do. Besides contributing to enhance people's work-life balance, they limit the pervasive phenomenon of involuntary part-time work, to the benefit of the society at large. In addition, meeting employees' needs may also benefit firms, as more satisfied workers are expected to perform better and establish a trusting relationship with their company. Our results have policy relevance: they suggest that policy makers should continue to actively undertake policies to increase the participation of women in leadership positions.

The rest of the paper is structured as follows: Section 2 provides a literature review; Section 3 presents the empirical model; Section 4 and 5 describe the Italian context and the data set used in the empirical analysis, respectively; Section 6 shows and discusses the results; and Section 7 concludes.

\section{Literature review}

In response to a recent increase in the female participation in leadership positions, a growing body of literature investigates if and how women leaders affect firm outcomes. 
While the bulk of the literature studies the impact of female leadership on performance and wage policies ${ }^{1}$, only three papers investigate how female leaders affect employment policies: Gagliarducci and Paserman (2015), Matsa and Miller (2013), and Matsa and Miller (2014). Among them, Gagliarducci and Paserman (2015) are the only to analyze, though marginally, the impact of female leaders on part-time employment, while Matsa and Miller (2013) and Matsa and Miller (2014) focus on their downsizing decisions.

Gagliarducci and Paserman (2015) use a matched employer-employee longitudinal data set for Germany for the period 1993-2012 to explore the relationship between female leaders (defined as top managers and working proprietors) and several performance, wage, and employment outcomes, including the use of part-time work. For what concerns part-time work, a simple OLS regression reports that female leaders are associated with a significantly higher number of female part-timers and a significantly lower number of male part-timers. However, once unobserved time-invariant heterogeneity is taken into account through $\mathrm{FE}$ estimation, both relations vanish, leading them to conclude that the effect is null. Anyhow, as they do nowise distinguish between voluntary and involuntary part-timers ${ }^{2}$, it is possible that their result is a hybrid capturing opposite behaviors of female leaders towards the two types of part-time work (voluntary versus involuntary). Moreover, the use of part-time work enters their empirical specification through (the natural logarithm of) the absolute number of female and male part-timers. Even if size dummies are included in their specifications, it is possible that the above findings capture, at least partly, a size effect.

Hence, our study represents a first 'systematic' attempt to examine the impact of female leaders on the use of part-time work, distinguishing, at least indirectly, between its voluntary and involuntary components.

The theoretical foundations of our paper (and, by the way, for every study assessing the economic impacts of female leaders) stem from the affirmative answers to two basic questions: (i) do different leaders lead to different firm outcomes? (ii) are women leaders different from male leaders?

The answer to the first question is 'yes'. In their seminal paper, Bertrand and Schoar

\footnotetext{
${ }^{1}$ For studies on performance: see, for instance, Smith et al. (2006) and Dezső and Ross (2012) for a positive impact; Adams and Ferreira (2009), Parrotta and Smith (2013), and Ahern and Dittmar (2012) for a negative impact; Rose (2007) for a null effect; and Flabbi et al. (2014) and Amore et al. (2014) for mixed effects. For studies on wage policies, examining the impact of female leaders on gender wage gap, see Bertrand et al. (2014), reporting no effect, and Cardoso and Winter-Ebmer (2010) and Tate and Yang (2015), documenting positive effects (i.e., reduction of gender pay gap).

${ }^{2}$ According to the OECD, the incidence of involuntary part-time work in Germany is not negligible. In the period considered by the study (1993-2012), it reached a peak of $19.2 \%$ in 2008 and always stayed above $11 \%$ after 2000.
} 
(2003) show that individual managers largely affect corporate policies (and performance). ${ }^{3}$ Constructing a manager-firm matched panel data set, they find that a significant proportion of heterogeneity in investment, financial, and organizational practices undertaken by the firm is explained by the manager fixed effects, that is, by the time-invariant characteristics of the individual manager.

The answer to the second question is again 'yes': several studies find that female leaders are different from male leaders in terms of leadership styles and values.

The human resource management and psychological literature highlights that female leaders often adopt a distinctive transformational leadership style (Rosener, 1990; Bass and Avolio, 2006; Eagly et al., 2003). Transformational leaders motivate their followers to higher levels of performance in several ways: they align followers around a common purpose and vision, encouraging them to go beyond their self-interests to concerns for their organization; they work in a strict relationship with their followers to stimulate proactive solutions to problems and optimistic behavior; and act as role models for them. Most importantly, transformational leaders take in great consideration the needs of their followers and the development of good interpersonal relationships with them (Bass and Avolio, 2006). According to the meta-analysis conducted on 45 studies on leadership styles, Eagly et al. (2003) find that female leaders show significantly higher individualized consideration for their followers compared to their male counterparts, reflected in their higher attention to the development and mentoring of followers and consideration of their individual needs. This distinctive feature of women leaders is likely to make them more concerned with employees' welfare than their male counterparts, possibly also with reference to working time arrangements.

In addition to such differences in interpersonal relationships, women and male leaders also differs in terms of values. Using data on leaders (directors, CEOs, and vice CEOs) of all publicly traded firms in Sweden in 2005, Adams and Funk (2012) find that female leaders systematically differ from their male counterparts in core values, even when firms fixed effects are included. They find that women leaders value more self-transcendence (benevolence and universalism) and correspondingly less self-enhancement (power and achievement) compared to their male counterparts. Such differences are rather large in magnitude and strongly significant. This finding strengthens the idea the female leaders may be more incline than male leaders to take care of employees' welfare and, consequently, to meet their needs.

The two studies by David Matsa and Amalia Miller are shedding more light on this. Using a quasi-natural experiment provided by a law imposing gender quotas on Norwegian

\footnotetext{
${ }^{3}$ This is not obvious. In fact, according to the neoclassical view, managers are homogeneous inputs in the production process and, consequently, perfect substitutes among each others (Bertrand and Schoar, 2003).
} 
boardrooms of publicly limited liability companies, their first paper (Matsa and Miller, 2013) finds that firms hit by the law were less likely to undertake workforce downsizing than the other (non-hit) firms. In their second paper (Matsa and Miller, 2014), the authors use a panel data set covering privately-owned US firms during the Great Recession (2006-2009) and find that female-owned firms were less likely than firms owned by males to downsize their workforce during periods of crisis. They also find that workers employed in female-owned firms operated with greater labor intensity shortly after the Great Recession and that femaleowned firms were less likely to hire workers on a temporary basis, suggesting that female leaders were pursuing labor hoarding practices. These findings suggest that the diversity in preferences and values between female and male leaders, with women being more generous, self-transcendent, and empathetic than men, actually come out in their employment policies.

Hence, our paper integrates this small but promising literature on the employment effects of female leadership concentrating on part-time work, complex in its nature, now representing a pervasive feature of work arrangements.

\section{Empirical model and identification}

To assess the impact of female managers on the use of part-time work, we consider a simple regression model of the following form:

$$
P T S_{i t}=\alpha+\beta F M S_{i t}+\gamma V_{i t}+\delta D_{i t}+\underbrace{w_{i t}+u_{i t}}_{\text {error term }}
$$

where: $P T S_{i t}$ is the share of part-timers over the total number of employees in firm $i$ at time $t ; F M S_{i t}$ is the share of female managers over the total number of managers; $V_{i t}$ is a vector of firm-level controls including the share of female, non-EU, temporary, blue-collar, and whitecollar workers; $D_{i t}$ is a set of dummy variables for year, size, macro-area, industry, and year interacted by industry; $w_{i t}$ is the part of the error term that is correlated with $F M S_{i t}$; and $u_{i t}$ is the part of the error term that is not correlated with $F M S_{i t}{ }^{4}$

Identifying the causal effect of interest crucially depends on the ability to take into account potentially confounding factors, whether they are observable or unobservable.

In relation to the observable controls, we consider the sector of economic activity and the share of female workers in the firm as essential variables to add to Equation (1). On the

\footnotetext{
${ }^{4}$ Implicitly, we assume that the zero values of the part-time share are generated by the same process that generates the positive values. In other words, we assume that firms that do not use part-time work can be thought of as using part-time work to a very low extent. This assumption is critical to model the part-time share according to the simple linear regression function in Equation (1) and, consequently, to allow us to deal with the unobserved time-invariant heterogeneity.
} 
one hand, as we shall see later in the discussion, it is a fact that some industries, such as the services and trade industries, employ part-timers more intensively and, at the same time, have a greater representation of females in the top layers of the firm. To properly control for these industry differentials, we insert dummies for industry as classified by the 2-digit Ateco 2007 code (78 different sectors). Moreover, we control for different paths over time of the industry differentials adding dummies for the interaction between industry and year. On the other hand, firms that, even after purging merely industry effects, are characterized by a greater proportion of female workers may experience an overrepresentation among parttimers (part-time jobs are for the most part accounted for by women) and female managers.

As for the unobserved confounding factors (i.e., elements inside $w_{i t}$ ), we regard the firm culture to be the major threat in the identification of the causal effect. For instance, it may be that firms that are naturally open and sensitive to employees' needs, are also more prone to concede part-time work to employees asking for it, even when part-time work does not fit the firm's needs. At the same time, such open-minded firms may also have a substantial fraction of women among the top and middle management. Or, for instance, firms that are less sensitive to social issues, such as their workers' welfare, may increment the employment of involuntary part-timers, when part-time work is part of an explicit corporate strategy. At the same time, female managers may be overrepresented into such type of firms, since they are generally involved in activities that 'require' female managers (e.g., retail and personal care services). ${ }^{5}$ In both circumstances, higher fractions of female managers would be found in association with higher levels of part-time work. Hence, not taking into account the firm culture would result in an (upwardly) biased estimate of the causal effect.

If one is willing to assume that the firm culture is not varying over time, i.e., that $w_{i t}=w_{i}$, it is possible to remove this potential source of endogeneity through the simple fixed-effects estimation. In practice, it consists of running an OLS regression on the withingroup transformation of Equation (1):

$$
\widetilde{P T S}_{i t}=\beta \widetilde{F M} S_{i t}+\gamma \widetilde{V}_{i t}+\delta \widetilde{D}_{i t}+\widetilde{u}_{i t}
$$

where the tilde operator indicates the within-group transformation: $\tilde{x}_{i t}=x_{i t}-\frac{1}{T} \sum_{t=1}^{T} x_{i t}{ }^{6}$

\footnotetext{
${ }^{5}$ Data confirm that female managers are indeed overrepresented in firms using part-time work as part of a corporate decision. This finding maintains even after taking into account the sector of economic activity. Note that this argument represents a threat in the identification of the causal effect to the extent that industry dummies cannot capture such segregation of female managers or that other, possibly unobserved, factors determine it.

${ }^{6}$ Note that, in this case, the dummies for macro-area and industry are excluded from the set of regressors, since they are time invariant and already accounted for by the within-group transformation.
} 
Considering the short time dimension of our panel (3 years), we argue that the assumption that the firm culture is time-invariant is plausible. Hence, we regard FE estimation as a solution to the potential problems of unobserved heterogeneity.

Nonetheless, for robustness purposes, we also resort to the instrumental variable estimation. We instrument the share of female managers over the total number of managers in the firm with its (two- or three-years) lag. This procedure delivers consistent estimates even in presence of firm culture that is varying over time, but only to the extent that past levels of female leadership can be excluded from the set of its determinants. ${ }^{7}$

Whether unobserved heterogeneity represents a real threat in the identification of the effect of interest, will be assessed by comparing results from the OLS, FE, and IV estimations of Equation (1).

\section{The Italian case}

According to the Istat, about 15\% of Italian employees worked part-time in 2010 and the general tendency is toward an increase in the use of part-time arrangements.

Many studies stress that part-time work can act as an instrument of work-life balance, allowing people to conciliate work better with their private life needs, such as child care or elderly care. Coherently with the fact that part-time work can be a work-life balance instrument for the workers, many firms (according to the 2010 RIL survey, they are about $60 \%$ of those using part-time arrangements) declare that they use part-time work to accommodate workers' needs for reduced working time. At the same time, according to the Istat, in 2010, $49 \%$ of Italian part-timers declared themselves to be involuntarily employed on a part-time basis, since they would have preferred a full-time job but were unable to find any.

These statistics shed light on the twofold nature of part-time work. Slightly more than a half $(100 \%-49 \%=51 \%)$ of part-timers are people who want to work on a part-time basis (i.e., voluntary part-timers) and that either work in firms that accommodate them for doing so or that need part-time work as the result of a corporate strategy. The remaining fraction of part-timers (49\%) is composed of people that do not like to work on a part-time basis (i.e., involuntary part-timers) and that are employed in firms that need part-time work to satisfy their needs, rather than in firms using part-time work as a mere accommodation instrument for people asking for it.

Hence, while voluntary part-time work should be encouraged by the policy makers as it enhances work-life balance of workers, the involuntary part-time work represents a dramatic

\footnotetext{
${ }^{7}$ To make the interpretation easier, we talk about 'firm culture'. However, FE (IV) estimation deals with the totality of the unobservable time-invariant (time-variant) heterogeneity among firms.
} 
problem of underemployment that they should try to address. Assessing whether female leaders can give their contribution in these directions is of crucial importance for helping policy makers to reach such goals, especially now that the representation of female leaders, though still modest, is growing faster year by year.

According to the Istat, female top and middle managers were only $21.9 \%$ of top and middle managers in the Italian private sector in 2008. In addition, such percentage hides a significant differential between the representation of females in the top versus middle management. In fact, the share of female middle managers was $24.9 \%$, whereas, the same share among top managers was only $12.2 \%$. However, also in response to the exhortations by the European Union to undertake concrete policies in favor of women ${ }^{8}$, the female representation among managers is rapidly growing: between 2008 and 2012, the share of female top managers is increased by $15.8 \%$, while the share of female middle managers is raised by $24.1 \%$. The Istat also reports that the percentage of female managers varies significantly across sectors. The services industry (in particular, the industries of the private instruction and the private health care) features the highest incidence of female managers, that, in extreme cases, reaches $50 \%$.

\section{Data}

To investigate the impact of female managers on the use of part-time work, we use the three available waves of the firm-level RIL survey, conducted in 2005, 2007, and 2010. Each wave of the survey interviews over 23,000 private sector Italian firms, including both partnerships and corporations. Since a sub-sample of the surveyed firms is followed over time, the complete RIL data set is partially panel. The data are uniquely rich concerning the composition of the workforce, including the numbers of part-time workers and top and middle managers, both males and females. Moreover, the RIL data provide information on the motivation for which the firm adopts part-time work. Finally, the data include an extensive set of firm-level controls (e.g., the industry classification and the place where the firm is located).

Since we are interested in the effect of female managers on the use of part-time work, it is reasonable to consider firms with a minimal organizational structure. For this reason, we restrict the attention to firm-year observations with at least 10 employees and employing at least one manager. ${ }^{9}$ Finally, we carry out an essential cleaning, aimed at removing

\footnotetext{
${ }^{8} \mathrm{~A}$ notable example, though beyond the time-scope of this paper, is represented by a law, entered in force at the beginning of 2012, that introduced gender quotas in the boardrooms of listed Italian firms.

${ }^{9}$ In any case, firm-year observations employing no managers would be automatically removed in the empirical analysis, since the share of female managers over the total number of managers (i.e., the regressor
} 
observations with missing values in the variables used in the estimation.

The final data set is composed of 12,298 firm-year observations for 9,117 firms.

The top panel of Table 1 presents the distribution of firms by the number of times that we observe them. Due to the partially-panel nature of the RIL data set, $72.7 \%$ of the firms are observed only once. About $20 \%$ of the firms are observed over 2 periods, while $7.6 \%$ of them are observed over 3 periods. ${ }^{10}$ The middle panel of Table 1 shows that the service and the manufacturing sectors are the largest, accounting for $41.5 \%$ and $39.6 \%$ of the firms, respectively. The trade and the construction industries represent $8.7 \%$ and $8.5 \%$ of the firms, respectively, while a tiny fraction refers to the mining industry (1.7\%). The lowest panel of Table 1 reports the distribution of firms by size. More than a half of companies (55.4\%) are small- or medium-sized, employing between 10 and 49 workers, while $31.7 \%$ and $13 \%$ of them are large or very large in size, employing between 50 and 249 workers or more than 250 workers, respectively.

Table 2 reports relevant summary statistics of the RIL data set. The firms in the sample employ on average 153 workers, but a half of them employ less than 42 workers, consistently with the Italian industrial structure in which small- and medium-sized firms represent the vast majority. In the average firm, $8.2 \%$ of employees work on a part-time basis. About $47 \%$ of the employees are blue-collar workers, $41.5 \%$ are white-collar workers, $6.9 \%$ are middle managers, and $4.5 \%$ fill a top managerial position. ${ }^{11}$ Female middle managers are, on average, $2.6 \%$ of employees, while female top managers are $1.3 \%$ of employees. In particular, in accordance with the statistics provided by the Istat, in the average firm, only $19.3 \%$ of top managers are females, while the share of females among middle managers is $31.4 \%$. Lastly, female workers are, on average, $35.4 \%$ of the firm workforce, workers that originate from non-EU countries are $5.1 \%$, and those employed with a fixed-term contract are $10 \%$.

Table 3 shows that part-time work is used by the great majority of firms: $71.2 \%$ of the firms employ at least one of their workers on a part-time basis. And as much as $10 \%$ of the firms are found to intensively use part-time work, employing at least $20 \%$ of their workforce on a part-time basis. Moreover, consistently with expectations, the use of parttime work varies significantly across industries. For instance, in the manufacturing firms, on average, $5.3 \%$ of the workers are part-timers, while, in the trade and services industries,

of interest) would be a missing value.

${ }^{10}$ From now on, when referring to 'firm', we actually mean 'firm-year observation'. If needed, we will make the distinction clear.

${ }^{11}$ When considering the sample of firms with at least 10 employees, without removing firms with no managers, the average share of middle managers in the firm lowers to $3.3 \%$, while the average share of top managers decreases to $2.1 \%$. This is consistent with the fact that a notable fraction $(51.6 \%)$ of companies with more that 10 employees does not have any employee filling a managerial position. 
they represent $9.6 \%$ and $11.6 \%$ of the total workforce in the firms, respectively. The lowest panel of Table 3 summarizes the answers given by firms employing at least one part-timer regarding the reason for their use of part-time work. The firms are asked to select the main motivation for their use of part-time work from the following checklist of options: (i) it is suitable for the production process; (ii) for facing programmed seasonality; (iii) it increases labor productivity; (iv) for accommodating workers' requests for shorter working time; (v) it is not affordable to employ workers full-time; (vi) other reasons. We then group the firms on the basis of whether part-time work is part of a deliberate corporate strategy or it is used to accommodate workers' needs. Firms indicating items (i), (ii), (iii), or (v) constitute the group of firms that use part-time work strategically, while firms specifying item (iv) constitute the group of firms using part-time work for accommodating workers' requests. Firms selecting item (vi) (i.e., the 'other reasons' item) constitute a third separated group, since we do not know whether they use part-time work strategically or to meet employees' requests. The vast majority of the firms using part-time work (67.1\%) declare that they use it to accommodate workers' requests for shorter working time. ${ }^{12}$ The remaining proportion of firms using parttime work is split between those using it strategically $(31.2 \%)$ and those choosing the 'other reasons' item (1.6\%). Among the firms declaring that they use part-time work strategically, the main reasons concern the suitability of part-time work for the production process $(20.3 \%$ of the firms using part-time work) and the preference to employ workers on a part-time basis because of budget constraints ( $4.8 \%$ of the firms using part-time work). Only a few firms using part-time work choose part-time work because they believe that part-timers are more productive than full-timers $(4.1 \%)$ and to face programmed seasonality $(2.1 \%)$.

Table 4 shows that more than a half $(55.6 \%)$ of firms employ at least one female manager. For $40.8 \%$ of the firms, at least $25 \%$ of their management is composed by women, while for $27 \%$ of the firms women represent at least a half of the management. In accordance with the official statistics, we observe considerable industry differentials in the female representation among managers. The values range from $34.3 \%$ of female managers over the total number of managers in firms operating in the service sector, to $24 \%$ in those belonging to the manufacturing sector.

Assessing whether and how female managers affect the use of part-time work by firms constitutes the object of the following econometric analysis. A first section explores the overall impact of female managers on the use of part-time work, while a second section investigates whether female managers behave differently when part-time work is used strategically com-

\footnotetext{
${ }^{12}$ This happens in all the macro-industries, that is, mining, manufacturing, construction, trade, and services.
} 
pared to when it is used to satisfy workers' requests. As discussed before, this distinction allows to assess, at least indirectly, how female managers behave towards involuntary and voluntary part-time work.

\section{Results and discussion}

\subsection{Overall impact on part-time work}

Table 5 reports the OLS, FE, and IV estimations of the overall impact of female managers on the use of part-time work, as modeled in the Equation (1).

The first column of the table reports the OLS estimates of Equation (1) including a large set of observable and potentially confounding firm-level controls. As discussed in Section 3, the sector of economic activity and the share of females in the firm seems to play a crucial role in explaining the presence part-time work and female managers, so we carefully control for both, also inserting interactions between industry and year dummies. We also add several other firm-level variables that may be correlated with both the use of part-time work and the female representation in the management of the firm. They include the shares of non-EU, temporary, blue- and white-collar workers (the reference group is the share of managers), and size, region, and year dummies. Note that this set of controls is maintained in all the following regressions. The effect of female managers on the use of part-time work is estimated to be negative, strongly significant. According to this estimate, a 1 standard deviation increase in the share of female managers over the total number of managers (0.363) decreases the share of part-time workers by 0.8 percentage points (i.e., $-0.021 * 0.363$ ). Equivalently, if the average firm passes from no women filling its management roles to only women filling them (i.e., the share of female managers over the total number of managers jumps from $0 \%$ to $100 \%$ ), the share of part-time workers is predicted to decrease by 2.1 percentage points, passing from an average share of $8.2 \%$ to a new share of $6.1 \%$.

As previously discussed, unobserved firm heterogeneity (including the firm culture), can represent a problem in the identification of the impact of interest. We explore this possibility through the FE and IV estimations of Equation (1). Columns 2 and 4 of Table 5 report the FE and IV estimates, respectively. Since the RIL data set is only partially panel, the FE estimation can be performed on a sub-sample including 5,666 firm-year observations. Furthermore, since the IV estimation needs at least two consecutive years of observations for the same firm and loses one year of observations (that is, 2005), the sub-sample is even smaller in this case, amounting to only 2,922 firm-year observations. For comparative purposes, we also report the OLS estimates computed on the same sub-samples used in the FE and IV estimations (Columns 3 and 5, respectively). According to the FE estimate, the impact of

female managers on the use of part-time work is negative, significantly different from zero 
at the $5 \%$ level, and virtually equal to the comparable OLS estimate. The IV estimate confirms the negative impact, which is somewhat larger in magnitude than the comparable OLS estimate $(-0.044$ versus -0.020$) .{ }^{13}$

Summarizing, we find that the overall impact of female managers on the use of part-time work is negative and significant, and maintains after controlling for unobserved time-invariant and time-varying heterogeneity. However, in view of the dual nature of part-time work, this result is not much informative and possibly hinders contrasting behaviors of female managers toward involuntary versus voluntary part-time work, which are explored in the following subsection.

\subsection{Impact on involuntary versus voluntary part-time work}

Since we have no direct information on the use of involuntary and voluntary part-time work at the firm-level, we resort to indirect information provided by the motivation for the firm's use of part-time work, which is available in the RIL data set. We split the sample of firms using part-time work into two categories: firm using it as a deliberate corporate strategy (for example, because it fits better the production process or to face expected peaks in the demand) and firms using it to accommodate workers' needs for part-time work. ${ }^{14}$ Assuming that the firms honestly report their motivation for their use of part-time work, we can legitimately exclude that firms declaring to use part-time work to accommodate workers' needs employ any involuntary part-time worker, so that all the involuntary part-timers are necessarily employed in firms deliberately using part-time work; at the same time, firms declaring to use part-time work to accommodate workers' needs do only employ voluntary part-time workers. Therefore, as long as firms truthfully report their motivation, separately analyzing the impact of female managers on the use of part-time work in these two types of firms allows to assess their behavior toward the involuntary and the voluntary part-time work.

Table 6 presents the results for the group of firms deliberately using part-time work.

According to the OLS estimates (Column 1), the effect of female managers on the use of part-time work is significantly negative and larger in magnitude than the overall impact (0.034 versus -0.021 ). Once the unobserved time-invariant heterogeneity is taken into account through FE estimation (Column 2), the estimated effect becomes very large in magnitude

\footnotetext{
${ }^{13}$ The first stage of the IV estimation confirms that the lagged share of female managers is a strong predictor of the current share, with a first-stage $\mathrm{F}$ statistic well above conventional threshold levels.

${ }^{14}$ The average share of part-timers in the firms is $18.1 \%$ for the first category and $8.5 \%$ for the latter. Consistently with this, firms strategically using part-time work employ about $67 \%$ of the total number of part-timers in our sample. The remaining fraction of part-timers (about 33\%) is employed in firms using it to accommodate workers' needs.
} 
$(-0.162)$ and remains significant at the $1 \%$ level. For firms adopting part-time work strategically, a 1 standard deviation increase in the share of female managers over the total number of managers (0.401) is predicted to cause a large drop in the share of part-time work by as much as 6.5 percentage points, thus passing from an average share of part-timers employed in the firm of $18.1 \%$ to a new share of $11.6 \%$.

The third column of Table 6 presents the FE estimates for a specification of Equation (1) that allows for non-linearities in the effect of interest. In fact, it is sensible to expect that the more the management of the firm is entrusted to women, the more they will be able to enforce their decisions, thus limiting the use of part-time work to a larger extent compared to when they are only a few. To assess whether this is the case, we insert two dummy variables indicating whether the firm employs relatively few or many female managers as a proportion of all managers. The first dummy takes a value of 1 if the firm employs at least one female manager and no more than $50 \%$ of the managers are females. The second dummy is equal to 1 if female managers are more than male managers. Results support our prediction. When female managers are relatively few, their impact on the use of parttime work becomes insignificant (though only marginally: p-value 0.120), suggesting that it is difficult for them to realize their objectives when male managers are the majority. On the contrary, when female managers are the majority, their impact on the use of part-time work is very large in magnitude and strongly significant. Having more than a half of female managers in the firm compared to having only male managers, is predicted to cause a drop in the share of part-timers by as much as 13.4 percentage points, thus lowering its average from $18.1 \%$ to $4.7 \%$.

Consistently with our expectations, these results suggest that female managers may limit the employment of involuntary part-timers, contemporaneously increasing the fraction of full-time employment, and that they become more successful in their objectives when they play a major role in the management. An explanation for these findings may reside in the fact that female managers are more concerned with their employees' welfare and more selftranscendent compared to their male counterparts, as Eagly and Carli (2007) and Adams and Funk (2012) point out. Moreover, our results seem to agree with Matsa and Miller (2013) and Matsa and Miller (2014) that the peculiar generous behavior of female managers can actually translate into real actions to protect their workers' needs. While this outcome would obviously benefit workers, improving their utility, and the society at large, limiting such a pervasive phenomenon of underemployment, it may reveal a good thing for the firms, too. As expected, involuntary part-timers systematically report lower levels of job satisfaction compared to full-timers and voluntary part-timers (Maynard et al., 2006), possibly translating into lowered productivity. Using the RIL data set, Devicienti et al. (2015) show 
that part-time work is detrimental to firm productivity (also) for firms strategically adopting it, suggesting that employing involuntary part-time workers may indeed lower firm performance. Moreover, firms protecting their employees' welfare generally gain favor of many customers, enhancing their social image.

Though there are valid reasons to believe that female managers reduce the involuntary fraction of part-time employment, we are aware that it is virtually possible that they only reduce the voluntary fraction, or both the involuntary and the voluntary fractions (recall that in firms deliberately using part-time work they coexist). Unfortunately, we have no possibility to give direct evidence on this. However, resorting to the information provided by the Istat on the involuntary part-time rate and the unemployment rate at a thin aggregation level, we provide evidence that our explanation may be indeed correct. In particular, we add to Equation (1) an interaction between the share of female managers over the total managers and a dummy variable indicating whether the firm operates in a context of high (i.e., above the median) involuntary part-time rate or unemployment rate, respectively.

If female managers really reduce the employment of involuntary part-timers, we expect that their effect in firms operating in contexts of high involuntary part-time work is stronger than in firms where the degree of involuntary part-time employment is likely to be smaller. Involuntary part-time rate is yearly provided at the macro-area and macro-industry level, identifying 48 cells. The first column of Table 7 reports the FE estimates for this exercise. Female managers operating in a context of high involuntary part-time work are associated with a significantly higher negative impact compared to those operating in a context of low involuntary part-time work, which have a relatively small and not significant negative impact on it. Hence, this result strongly supports the interpretation that female managers limit the employment of the involuntary and not the voluntary part-time workers, correspondingly increasing the fraction of full-time employment.

The second column of Table 7 gives further evidence of this, exploiting the information on the unemployment rate yearly provided at the province level, identifying as much as 330 cells. Arguably, the unemployment rate is strictly related to the degree of involuntary parttime work. When there is high unemployment, the bargaining power of firms increases to the detriment of workers and part-time work may represent the only alternative to unemployment. Hence, in cases of high unemployment, involuntary part-time work is likely to be higher. The results again support our interpretation. When controlling for time-invariant unobserved heterogeneity, female managers working in conditions of high unemployment are estimated to have a significantly larger negative effect on part-time work compared to those working in contexts of low unemployment, which are estimated to have a relatively small and not significant impact on it. 
To assess whether female managers also concede more part-time work to employees' asking for it, as our expectations would suggest, Table 8 reports the results for the group of firms declaring to adopt part-time work to accommodate workers' needs.

According to the OLS estimates (Column 1), the impact of female managers on the use of part-time work is negative, though lower in magnitude compared to that for the general case (-0.016 versus -0.021), and significantly different from zero at any conventional level, suggesting that female managers may be less willing than male managers to concede part-time work. However, once we control for the unobservable time-invariant heterogeneity through FE estimation (Column 2), the estimated effect becomes largely insignificant. This result, in contrast with our prediction, indicates that female managers would not accommodate workers' requests for part-time work differently from their male counterparts.

However, this result crucially hinges on the truthfulness of the motivation given for the use of part-time work. While firms actually using part-time work to satisfy the workers' needs do not have any evident reason to lie about their real motivation, firms actually using part-time work strategically do have valid motivations to hide the truth. To answer in a socially desirable way and/or to hide the employment of involuntary part-time workers, such firms may falsely declare to adopt part-time work to meet the employees' needs. If this happens, the group of firms declaring to use part-time work to accommodate workers' requests includes some firms actually using it strategically, thus mudding our last result.

To bypass this problem, we try to identify firms using part-time work to accommodate workers' requests on the basis of the amount of part-time work that they use. In fact, it is reasonable to assume that firms using part-time work to satisfy their employees' needs use relatively less part-time work compared to firms adopting it as a corporate strategy. ${ }^{15}$ To perform this exercise, we divide the sample of firms using part-time work into two subsamples: firms using a small amount of part-time work (i.e., below the median) and firms intensively using it (i.e., above the median). ${ }^{16}$

According to the FE estimates (Column 1 of Table 9), in firms using relatively low amounts of part-time work, female managers positively and significantly impact its use, at least when they represent the majority of the management. If the management of a firm

\footnotetext{
${ }^{15}$ Our data support this idea. As shown before, firms declaring to use part-time work strategically employ on average as much as $18.1 \%$ of their workforce on a part-time basis, while among firms declaring to use part-time work for accommodation purposes (even if some of them are possibly lying) this percentage is much lower $(8.5 \%)$.

${ }^{16}$ The median share of part-time work is $6.7 \%$. Firms below the median employ on average $3.4 \%$ of their workforce on a part-time basis, while firms above the median employ on average as much as $19.9 \%$ of their workforce part-time. Since we perform separate FE estimations on the two groups of firms, we lose observations for firms that are above the median for some years and below the median for other years to the extent that only one panel observation remain in one of the two groups.
} 
using relatively low quantities of part-time work passes from having no women to having at least $50 \%$ of women, part-time work is estimated to increase by 0.5 percentage points, passing from an average share of $3.4 \%$ to a new share of $3.9 \%{ }^{17}$ This result supports our expectation that female managers meet their employees' needs more than their male counterparts also granting more often part-time work to employees asking for it, thus allowing them to better combine work and private life needs. Firms may also get the possibility to better their corporate image, through the involvement in active practices aimed at granting a better work-life balance to their employees.

\section{Conclusions}

Exploring the impact of female managers on the use of part-time work, this paper integrates a small but growing literature on the employment outcomes of female leaders.

Using three waves of a uniquely rich survey on Italian private firms, we find that female managers heavily limit the employment of involuntary part-timers, correspondingly providing more full-time employment, and that they are more prone to concede part-time positions to employees asking for them compared to male managers. Therefore, female managers are found to meet their employees' needs more than their male counterparts do, at least for what concerns working time arrangements.

Considering the dramatic diffusion of the involuntary part-time work in Italy, the social role of female managers is plain: involuntary part-timers were as many as $49 \%$ of part-time workers in 2010. They are people working part-time even if they would prefer to work full-time, but did not find any full-time job and end up in the count of the underemployed people. Female managers working in firms most likely employing involuntary part-time workers significantly limit their employment, correspondingly offering more full-time positions: according to our estimates, a shift from no female managers to at least $50 \%$ of female managers as a proportion of the total number of managers in such firms decreases the share of part-timers by as much as 13.4 percentage points, from an average share of $18.1 \%$ to a share of $4.7 \%$.

Besides improving the workers' welfare, granting full-time employment to people needing

\footnotetext{
${ }^{17}$ Conversely, and in accordance with the previous findings on the involuntary part-time work, female managers significantly limit the use of part-time arrangements in firms intensively using them (Table 9, Column 2). Note that these coefficients are smaller than those found when considering firms declaring to strategically use part-time work (Table 6, Column 3). In fact, we can not exclude that firms using relatively large quantities of part-time work actually do so to accommodate workers' requests, thus diminishing the negative effect. Anyhow, to assess the impact of female managers on the involuntary part-time work we rely on the results presented in Table 6 (and Table 7), since there is no evident reason to believe that firms declaring to strategically use part-time work are lying on their real motivation.
} 
it, and benefiting the society at large, heavily limiting the diffusion of involuntary part-time employment, this outcome may also be beneficial for firms. In fact, it is plausible that more satisfied workers perform better and help to create a united and cohesive working team, thus enhancing firm productivity. Using the RIL data set, Devicienti et al. (2015) find that part-time work dampens productivity in firms where involuntary part-timers are employed (i.e., those using part-time work to satisfy their, the firm's, needs), thus suggesting that employing involuntary part-time workers may indeed result in lowered firm performance. Moreover, being more sensitive to the employees' needs may also enhance the image that the customers and the community have of the firm.

Female managers are also found to concede more part-time work when the employees ask for it, thus contributing to enhance their balance between work and private life undertakings, such as child care or elderly care. For the same reasons outlined before, the firms may also take benefit from this behavior: from a happier, more cohesive workforce and from an enhanced social image.

The explanations for these findings may be found in the acknowledged peculiar attitudes of female managers: they are found to be more self-transcendent (Adams and Funk, 2012) and more reactive to their employees' needs (Eagly and Carli, 2007). While Matsa and Miller (2013) and Matsa and Miller (2014) find such attitudes in action when looking at downsizing decisions of female versus male managers, we discover them in relation to decisions regarding working time arrangements.

All in all, according to our and their results, the society has much to lose by not having more female leaders, thus suggesting that policy makers should keep on investing in active policies aimed at increasing the female participation in leadership positions. 
Table 1: Distribution of firms by number of panel observations and distribution of firm-year observations by industry and size

\begin{tabular}{l|l|l}
\hline \hline Number of panel observations & Firms & Observations \\
\hline 1 & 6,632 & 6,632 \\
2 & 1,789 & 3,578 \\
3 & 696 & 2,088 \\
\hline Total & 9,117 & 12,298 \\
\hline \hline Industry & Observations & Percentage \\
\hline Mining & 207 & 1.7 \\
Manufacturing & 4,873 & 39.6 \\
Construction & 1,047 & 8.5 \\
Trade & 1,070 & 8.7 \\
Services & 5,101 & 41.5 \\
\hline Total & 12,298 & 100 \\
\hline \hline Size & Observations & Percentage \\
\hline $10-19$ & 3,434 & 27.9 \\
$20-49$ & 3,374 & 27.4 \\
$50-249$ & 3,896 & 31.7 \\
$250+$ & 1,594 & 13.0 \\
\hline Total & 12,298 & 100 \\
\hline \hline
\end{tabular}

Source: RIL data set (years: 2005, 2007, and 2010)

Table 2: Sample summary statistics

\begin{tabular}{ll|l}
\hline \hline Variable & Mean & Standard deviation \\
\hline Employees & 152.588 & 541.949 \\
\hline Part-time workers' share of the workforce & 0.082 & 0.141 \\
\hline Blue-collar workers' share of the workforce & 0.471 & 0.317 \\
White-collars workers' share of the workforce & 0.415 & 0.289 \\
Middle managers' share of the workforce & 0.069 & 0.103 \\
Top managers' share of the workforce & 0.045 & 0.064 \\
Managers' share of the workforce* & 0.113 & 0.121 \\
Female middle managers' share of the workforce & 0.026 & 0.057 \\
Female top managers' share of the workforce & 0.013 & 0.038 \\
Female managers' share of the workforce & 0.038 & 0.068 \\
\hline Female middle managers as a proportion of all middle managers & 0.314 & 0.370 \\
Female top managers as a proportion of all top managers & 0.193 & 0.343 \\
Female managers as a proportion of all managers & 0.288 & 0.363 \\
\hline Females' share of the workforce & 0.354 & 0.254 \\
Non-EU workers' share of the workforce & 0.051 & 0.117 \\
Temporary workers' share of the workforce & 0.100 & 0.149 \\
\hline \hline
\end{tabular}

Source: RIL data set (years: 2005, 2007, and 2010)

'Managers' are top and middle managers. 
Table 3: Part-time work: use, industry differentials, and reasons

\begin{tabular}{l|l|l}
\hline \hline Use & Observations & Percentage \\
\hline Some use of part-time work (at least one part-time worker) & 8,761 & 71.2 \\
Heavy use of part-time work (at least 20\% of part-time workers) & 1,228 & 10.0 \\
\hline \hline Industry differentials & Mean & Standard deviation \\
\hline Mining - part-time workers' share of the workforce & 0.041 & 0.059 \\
Manufacturing - part-time workers' share of the workforce & 0.053 & 0.078 \\
Construction - part-time workers' share of the workforce & 0.045 & 0.085 \\
Trade - part-time workers' share of the workforce & 0.096 & 0.126 \\
Services - part-time workers' share of the workforce & 0.116 & 0.187 \\
\hline \hline Reasons & Observations & Percentage \\
\cline { 1 - 2 } For accommodating workers' requests for shorter working time & 5,882 & 67.1 \\
\cline { 1 - 2 } Strategic use of part-time work & 2,737 & 31.2 \\
it is suitable for the production process & 1,781 & 20.3 \\
it is not affordable to employ workers full-time & 418 & 4.8 \\
it increases labor productivity & 357 & 4.1 \\
for facing programmed seasonality & 181 & 2.1 \\
\hline Other reasons & 142 & 1.6 \\
\hline Total & 8,761 & 100 \\
\hline \hline
\end{tabular}

Source: RIL data set (years: 2005, 2007, and 2010)

Table 4: Female managers: representation and industry differentials

\begin{tabular}{l|l|l}
\hline \hline Representation & Observations & Percentage \\
\hline $\begin{array}{l}\text { Some representation (at least one female manager) } \\
\text { Modest representation (at least 25\% of female managers }\end{array}$ & 6,838 & 55.6 \\
as a proportion of managers) & 5,014 & 40.8 \\
$\begin{array}{l}\text { Heavy representation (at least 50\% of female managers } \\
\text { as a proportion of managers) }\end{array}$ & 3,323 & 27.0 \\
\hline \hline Industry differentials & Mean* & Standard deviation \\
\hline Mining - female managers as a proportion of all managers & 0.270 & 0.386 \\
Manufacturing - female managers as a proportion of all managers & 0.240 & 0.349 \\
Construction - female managers as a proportion of all managers & 0.267 & 0.398 \\
Trade - female managers as a proportion of all managers & 0.264 & 0.341 \\
Services - female managers as a proportion of all managers & 0.343 & 0.364 \\
\hline \hline
\end{tabular}

Source: RIL data set (years: 2005, 2007, and 2010) 
Table 5: Results: overall impact of female managers on the use of part-time work; estimation methods: OLS, FE, IV

\begin{tabular}{|c|c|c|c|c|c|}
\hline \multicolumn{6}{|c|}{ Dependent variable: part-time workers' share of the workforce } \\
\hline & 1 & 2 & 3 & 4 & 5 \\
\hline Variables & OLS & FE & OLS-compFE & IV & OLS-compIV \\
\hline \multirow{2}{*}{ Female managers as a proportion of all managers } & $-0.021^{* * *}$ & $-0.021^{* *}$ & $-0.024^{* * *}$ & $-0.044^{* *}$ & $-0.020^{* *}$ \\
\hline & $(0.004)$ & $(0.009)$ & $(0.006)$ & $(0.020)$ & $(0.010)$ \\
\hline \multirow{2}{*}{ Females' share of the workforce } & $0.196^{* * *}$ & $0.159^{* * *}$ & $0.189^{* * *}$ & $0.198^{* * *}$ & $0.188^{* * *}$ \\
\hline & $(0.008)$ & $(0.024)$ & $(0.011)$ & $(0.018)$ & $(0.016)$ \\
\hline \multirow[t]{2}{*}{ Temporary workers' share of the workforce } & 0.002 & 0.006 & 0.027 & 0.028 & 0.030 \\
\hline & $(0.017)$ & $(0.021)$ & $(0.018)$ & $(0.023)$ & $(0.024)$ \\
\hline \multirow[t]{2}{*}{ Non-EU workers' share of the workforce } & -0.012 & 0.001 & -0.011 & -0.016 & -0.014 \\
\hline & $(0.009)$ & $(0.026)$ & $(0.016)$ & $(0.030)$ & $(0.030)$ \\
\hline \multirow[t]{2}{*}{ Blue-collar workers' share of the workforce } & $0.085^{* * *}$ & $0.080^{* *}$ & $0.091^{* * *}$ & $0.093^{* * *}$ & $0.099 * * *$ \\
\hline & $(0.013)$ & $(0.036)$ & $(0.020)$ & $(0.022)$ & $(0.023)$ \\
\hline \multirow[t]{2}{*}{ White-collar workers' share of the workforce } & $0.080 * * *$ & $0.084^{* *}$ & $0.088^{* * *}$ & $0.090^{* * *}$ & $0.098^{* * *}$ \\
\hline & $(0.014)$ & $(0.036)$ & $(0.022)$ & $(0.025)$ & $(0.026)$ \\
\hline Size dummies & yes & yes & yes & yes & yes \\
\hline Year dummies & yes & yes & yes & yes & yes \\
\hline Macro-area dummies & yes & - & yes & yes & yes \\
\hline Industry dummies & yes & - & yes & yes & yes \\
\hline Year/industry dummies & yes & yes & yes & yes & yes \\
\hline Firm-year observations & 12,298 & 5,666 & 5,666 & 2,922 & 2,922 \\
\hline Firms & 9,117 & 2,485 & 2,485 & 2,226 & 2,226 \\
\hline
\end{tabular}

Source: RIL data set (years: 2005, 2007, and 2010)

Robust standard errors in parentheses; ***,**, and * denote, respectively, the 1\%, 5\%, and $10 \%$ significance level. The reference group for blue- and white-collar workers' share of the workforce is managers' share of the workforce. The size dummies collect 4 dummies: 10-19 employees, 20-49 employees, 50-249 employees, and more than 250 employees; the macro-area dummies consist of 4 dummies: North-West, North-East, Central area, and South of Italy; the industry dummies account for 78 dummies, 1 for each 2-digit Ateco 2007 industry; and the year/industry dummies are the interactions between year and industry dummies, as previously defined. 
Table 6: Results: impact of female managers on the use of involuntary parttime work (sub-sample of firms strategically using part-time work); estimation methods: OLS, FE

\begin{tabular}{lcc|c}
\hline \hline \multicolumn{3}{c}{ Dependent variable: part-time workers' share of the workforce } & \\
\hline & 1 & 2 & 3 \\
Variables & OLS & FE & FE \\
\hline Female managers as a proportion of all managers & $-0.034^{* * *}$ & $-0.162^{* * *}$ & \\
& $(0.011)$ & $(0.050)$ & \\
\hline At least 1 - 50\% of female managers as a proportion of all managers & & & -0.052 \\
& & & $(0.034)$ \\
At least 50\% of female managers as a proportion of all managers & & & $-0.134^{* * *}$ \\
& & & $(0.043)$ \\
\hline Females' share of the workforce & $0.292^{* * *}$ & $0.295^{* * *}$ & $0.264^{* * *}$ \\
& $(0.020)$ & $(0.100)$ & $(0.099)$ \\
Temporary workers' share of the workforce & 0.016 & -0.017 & -0.009 \\
& $(0.026)$ & $(0.078)$ & $(0.077)$ \\
Non-EU workers' share of the workforce & 0.002 & 0.110 & 0.103 \\
& $(0.023)$ & $(0.086)$ & $(0.086)$ \\
Blue-collar workers' share of the workforce & $0.136^{* * *}$ & -0.020 & -0.030 \\
& $(0.046)$ & $(0.132)$ & $(0.132)$ \\
White-collar workers' share of the workforce & $0.122^{* * *}$ & -0.053 & -0.062 \\
& $(0.047)$ & $(0.121)$ & $(0.120)$ \\
Size dummies & yes & yes & yes \\
Year dummies & yes & yes & yes \\
Macro-area dummies & yes & - & - \\
Industry dummies & yes & - & - \\
Year/industry dummies & yes & yes & yes \\
\hline Firm-year Observations & 2,737 & 1,119 & 1,119 \\
Firms & 2,468 & 850 & 850 \\
\hline \hline
\end{tabular}

Source: RIL data set (years: 2005, 2007, and 2010)

The estimates are performed on the sub-sample of firm-year observations using part-time work to satisfy the firm's needs (2,737). Note that to split the sample on the basis of the reason for part-time work use, we have to remove those observations (amounting to 142) for which the item 'other reasons' has been chosen, since we do not know whether they belong to the first or the second group. Robust standard errors in parentheses; ***, **, and * denote, respectively, the 1\%, 5\%, and 10\% significance level. For the rest, see footnotes of Table 5. 
Table 7: Results: impact of female managers on the use of involuntary part-time work (sub-sample of firms strategically using part-time work; interaction with involuntary part-time work rate and unemployment rate at a fine aggregation level); estimation method: FE

\begin{tabular}{|c|c|c|}
\hline \multicolumn{3}{|l|}{ Dependent variable: part-time workers' share of the workforce } \\
\hline & 1 & 2 \\
\hline Variables & FE & FE \\
\hline Female managers as a proportion of all managers & $\begin{array}{l}-0.077 \\
(0.069)\end{array}$ & $\begin{array}{l}-0.085 \\
(0.055)\end{array}$ \\
\hline Female managers as a proportion of all managers $*$ High involuntary part-time rate & $\begin{array}{c}-0.147^{*} \\
(0.081)\end{array}$ & \\
\hline High involuntary part-time rate & $\begin{array}{c}0.088^{* *} \\
(0.035) \\
\end{array}$ & \\
\hline Female managers as a proportion of all managers $*$ High unemployment rate & & $\begin{array}{c}-0.145^{* *} \\
(0.064)\end{array}$ \\
\hline High unemployment rate & & $\begin{array}{c}0.014 \\
(0.030) \\
\end{array}$ \\
\hline Females' share of the workforce & $\begin{array}{c}0.301^{* * *} \\
(0.103)\end{array}$ & $\begin{array}{c}0.295^{* * *} \\
(0.103)\end{array}$ \\
\hline Temporary workers' share of the workforce & $\begin{array}{l}-0.040 \\
(0.082)\end{array}$ & $\begin{array}{l}-0.044 \\
(0.083)\end{array}$ \\
\hline Non-EU workers' share of the workforce & $\begin{array}{c}0.117 \\
(0.090)\end{array}$ & $\begin{array}{c}0.099 \\
(0.087)\end{array}$ \\
\hline Blue-collar workers' share of the workforce & $\begin{array}{c}-0.026 \\
(0.132)\end{array}$ & $\begin{array}{l}-0.019 \\
(0.132)\end{array}$ \\
\hline White-collar workers' share of the workforce & $\begin{array}{c}-0.051 \\
(0.121)\end{array}$ & $\begin{array}{l}-0.046 \\
(0.118)\end{array}$ \\
\hline Size dummies & yes & yes \\
\hline Year dummies & yes & yes \\
\hline Macro-area dummies & - & - \\
\hline Industry dummies & - & - \\
\hline Year/industry dummies & yes & yes \\
\hline Firm-year Observations & 1,119 & 1,119 \\
\hline Firms & 850 & 850 \\
\hline
\end{tabular}

Source: RIL data set (years: 2005, 2007, and 2010)

The estimates are performed on the sub-sample of firm-year observations using part-time work to satisfy the firm's needs. The involuntary part-time rate is disaggregated at the macro-area (North-West, North-East, Central area, and South) and macro-industry (mining and manufacturing, construction, trade, and services) level, identifying 48 cells (16 categories $* 3$ years). The unemployment rate is disaggregated at the province level, identifying 330 cells (110 provinces $* 3$ years). Robust standard errors in parentheses; ***, **, and * denote, respectively, the 1\%, 5\%, and 10\% significance level. For the rest, see footnotes of Table 5 . 
Table 8: Results: impact of female managers on the use of voluntary part-time work (sub-sample of firms accommodating workers' requests for part-time work); estimation methods: OLS, FE

\begin{tabular}{lcc}
\hline \hline \multicolumn{3}{c}{ Dependent variable: part-time workers' share of the workforce } \\
\hline & 1 & 2 \\
Variables & OLS & FE \\
\hline Female managers as a proportion of all managers & $-0.016^{* * *}$ & -0.019 \\
& $(0.005)$ & $(0.017)$ \\
\hline Females' share of the workforce & $0.130^{* * *}$ & $0.075^{* * *}$ \\
& $(0.008)$ & $(0.023)$ \\
Temporary workers' share of the workforce & $-0.028^{* *}$ & -0.026 \\
& $(0.014)$ & $(0.017)$ \\
Non-EU workers' share of the workforce & -0.019 & -0.032 \\
& $(0.013)$ & $(0.044)$ \\
Blue-collar workers' share of the workforce & $0.030^{*}$ & 0.005 \\
& $(0.016)$ & $(0.030)$ \\
White-collar workers' share of the workforce & $0.036^{* *}$ & 0.016 \\
& $(0.017)$ & $(0.030)$ \\
Size dummies & yes & yes \\
Year dummies & yes & yes \\
Macro-area dummies & yes & - \\
Industry dummies & yes & - \\
Year/industry dummies & yes & yes \\
\hline Firm-year Observations & 5,882 & 3,156 \\
Firms & 4,542 & 1,816 \\
\hline \hline
\end{tabular}

Source: RIL data set (years: 2005, 2007, and 2010)

The estimates are performed on the sub-sample of firm-year observations using part-time work for accommodating workers' requests for shorter working hours (5,882). Robust standard errors in parentheses; ***, **, and * denote, respectively, the 1\%, 5\%, and 10\% significance level. For the rest, see footnotes of Table 5 . 
Table 9: Results: impact of female managers on the use of voluntary and involuntary part-time work (division of firms using part-time work by intensity of its use - below the median and above the median); estimation method: FE

\begin{tabular}{|c|c|c|}
\hline \multicolumn{3}{|c|}{ Dependent variable: part-time workers' share of the workforce } \\
\hline & 1 & 2 \\
\hline Variables & FE (below the median) & FE (above the median) \\
\hline \multirow[t]{2}{*}{ At least $1-50 \%$ of female managers as a proportion of all managers } & 0.002 & $-0.034^{* *}$ \\
\hline & $(0.001)$ & $(0.015)$ \\
\hline \multirow{2}{*}{ At least $50 \%$ of female managers as a proportion of all managers } & $0.005^{* *}$ & $-0.046^{* *}$ \\
\hline & $(0.002)$ & $(0.022)$ \\
\hline \multirow[t]{2}{*}{ Females' share of the workforce } & $0.018^{* * *}$ & $0.140^{* * *}$ \\
\hline & $(0.006)$ & $(0.046)$ \\
\hline \multirow{2}{*}{ Temporary workers' share of the workforce } & -0.006 & 0.085 \\
\hline & $(0.005)$ & $(0.063)$ \\
\hline \multirow[t]{2}{*}{ Non-EU workers' share of the workforce } & $0.012^{*}$ & -0.039 \\
\hline & $(0.007)$ & $(0.073)$ \\
\hline \multirow[t]{2}{*}{ Blue-collar workers' share of the workforce } & 0.003 & -0.005 \\
\hline & $(0.009)$ & $(0.049)$ \\
\hline \multirow[t]{2}{*}{ White-collar workers' share of the workforce } & 0.005 & 0.002 \\
\hline & $(0.009)$ & $(0.049)$ \\
\hline Size dummies & yes & yes \\
\hline Year dummies & yes & yes \\
\hline Macro-area dummies & - & - \\
\hline Industry dummies & - & - \\
\hline Year/industry dummies & yes & yes \\
\hline Firm-year Observations & 1,853 & 1,387 \\
\hline Firms & 833 & 632 \\
\hline
\end{tabular}

Source: RIL data set (years: 2005, 2007, and 2010)

Firms using part-time work are divided into two groups on the basis of the intensity of the use of part-time work: below the median level and above the median level. Robust standard errors in parentheses; ***, **, and * denote, respectively, the 1\%, 5\%, and 10\% significance level. For the rest, see footnotes of Table 5. 


\section{References}

Adams, R., Funk, P., 2012. Beyond the Glass-Ceiling: Does Gender Matter? Management Science 58 (2), 219-235.

Adams, R. B., Ferreira, D., 2009. Women in the Boardroom and Their Impact on Governance and Performance. Journal of Financial Economics 94, 291-309.

Ahern, K. R., Dittmar, A. K., 2012. The Changing of the Boards: the Impact on Firm Valuation of Mandated Female Board Representation. The Quarterly Journal of Economics $127,137-197$.

Amore, M. D., Garofalo, O., Minichilli, A., 2014. Gender Interactions Within the Family Firms. Management Science 60 (5), 1083-1097.

Bass, B., Avolio, B. J., 2006. Shatter the Glass Ceiling: Women may Make Better Managers. Human Resource Management 33 (4), 549-560.

Bertrand, M., Black, S. E., Jensen, S., Lleras-Muney, A., 2014. Breaking the Glass Ceiling? The Effect of Board Quotas on Female Labor Market Outcomes in Norway, NBER Working Paper No. 20256.

Bertrand, M., Schoar, A., 2003. Managing with Style: The Effect of Managers on Firm Policies. The Quarterly Journal of Economics 118 (4), 1169-1208.

Cardoso, A. R., Winter-Ebmer, R., 2010. Female-Led Firms and Gender Wage Policies. Industrial \& Labor Relations Review 64 (1), 143-163.

Devicienti, F., Grinza, E., Vannoni, D., 2015. The Impact of Part-Time Work on Firm Total Factor Productivity: Evidence from Italy, IZA Discussion Paper No. 9463.

Dezső, C. L., Ross, D. G., 2012. Does Female Representation in Top Management Improve Firm Performance? A Panel Data Investigation. Strategic Management Journal 33 (9), 1072-1089.

Eagly, A., Carli, L. L., 2007. Through the Labyrinth: The Truth about How Women Become Leaders. Harvard Business School Press, Boston.

Eagly, A. H., Johannesen-Schmidt, M. C., van Engen, M. L., 2003. Transformational, Transactional, and Laissez-Faire Leadership Styles: A Meta-Analysis Comparing Women and Men. Psychological Bulletin 129 (4), 569591. 
Flabbi, L., Macis, M., Moro, A., Schivardi, F., 2014. Do Female Executives Make a Difference? The Impact of Female Leadership on Gender Gaps and Firm Performance, IZA Discussion Paper No. 8602.

Gagliarducci, S., Paserman, D., 2015. The Effect of Female Leadership on Establishment and Employee Outcomes: Evidence from Linked Employer-Employee Data. Research in Labor Economics 41, 343-375.

Matsa, D. A., Miller, A. R., 2013. A Female Style in Corporate Leadership? Evidence from Quotas. American Economic Journal: Applied Economics 5 (3), 136-169.

Matsa, D. A., Miller, A. R., 2014. Workforce Reductions at Women-Owned Businesses in the United States. Industrial \& Labor Relation Review 67 (2), 422-452.

Maynard, D. C., Todd, A. J., Maynard, A. M., 2006. Underemployment, Job Attitudes, and Turnover Intentions. Journal of Organizational Behaviour 27 (4), 509-536.

Parrotta, P., Smith, N., 2013. Female-Led Firms: Performance and Risk Attitudes, IZA Discussion Paper No. 7613.

Rose, C., 2007. Does Female Board Representation Influence Firm Performance? The Danish Evidence. Corporate Governance: An International Review 15 (2), 404-413.

Rosener, J. B., 1990. Ways Women Lead. Harvard Business Review 68 (6), 119-125.

Smith, N., Smith, V., Verner, M., 2006. Do Women in Top Management Affect Firm Performance? A Panel Study of 2,500 Danish Firms. International Journal of Productivity and Performance Management 55 (7), 569-593.

Tate, G., Yang, L., 2015. Female Leadership and Gender Equity: Evidence from Plant Closure. Journal of Financial Economics 117, 77-97. 